\title{
FREQUENCY OF ARTHROPODS DAILY VISITS ON Centella asiatica L. AND Synedrlla nodiflora (L) GAERTN IN THE WONOSARI SINGOSARI TEA PLANTATION AREA, MALANG REGENCY
}

\author{
Dora Dayu Rahma Turista ${ }^{{ }^{*}, \text { Fatchur Rohman }^{2} \text {, Bagyo Yanuwiadi }}{ }^{3}$ \\ ${ }^{1}$ STIKes Hutama Abdi Husada, Tulungagung \\ ${ }^{2}$ Biology Education Department - State University of Malang \\ ${ }^{3}$ Biology Department, Brawijaya University \\ *Corresponding author : doraturistaofficial@gmail.com
}

\begin{abstract}
ARTICLE INFO
Article history

Received $25^{\text {th }}$ of Feb., 2020

Revised $10^{\text {th }}$ of March, 2020

Accepted $10^{\text {th }}$ of April, 2020

Published $21^{\text {st }}$ of May, 2020

Keywords

Composition

Frequency of Visiting Temporal

Distribution Centella asiatica $L$

Synedrella nodiflora $(L)$ Gaertn
\end{abstract}

\section{ABSTRACT}

The purpose of this research is to find the temporal distribution pattern of the visiting of Arthropods on these wild plants. This descriptive and explorative research was carried out in the Wonosari tea plantation, Singosari, Malang in March 2011. The visual control method for these purposes was adopted from the modification of the visual control method developed by Frei and Manhart (1992). Observations were done with 10 repeats, consisting of 10 tempos with 15 minutes duration. Data relating to the temporal distribution of Arthropods on these wild plants were presented as diagrams and interpreted descriptively. The result of this research can be described as follows: There was a difference between the temporal distribution of Arthropod visiting the wild plants Centella asiatica L. and Synedrella nodiflora (L) Gaertn. For the Centella asiatica L the highest visitor number was at 10.00 am while for the wild plant Synedrella nodiflora (L) Gaertn it was at $11.20 \mathrm{am}$.

\section{A. INTRODUCTION}

The tea plant is a subtropical plant that has long been known in human civilization.

Tea is one of the leading commodities in the plantation sector and many farmers are cultivating it. In the cultivation of agriculture can not be separated from plant pests, as well as in the cultivation of tea plant agriculture. In the cultivation of tea in Indonesia, pest problems cause significant crop damage. The intensity of pest disorders in tea plants is generally quite high (Styamidjaja, 2000).

Initially, pest control was carried out simply, namely biologically using simple tools such as bat. The vast area of agriculture makes these simple methods no longer effective to use because they are unable to stem the increase in pest populations so that pest control is done chemically, using synthetic pesticides. The use of synthetic pesticides is detrimental 
to the environment, health, and economy. Implementation of pest control in tea plantations needs to be improved with the main principle of choosing an environmentally friendly way without using chemicals. As an alternative to controlling and suppressing chemical pesticides, specifically to protect tea plants from pests, the Gambung Tea and Quinine Research Center (PPTK) has issued recommendations using biological control methods by utilizing natural enemies. The different types of biological control agents (BCAs) including predators, parasites (parasitoids), and pathogens (fungi, bacteria, viruses, and virus-like particles, protozoa, and nematodes) (Kwenti, 2017).

Rohman (2008) states that the biological control that can be applied is the empowerment of biotic factors in the tea agroecosystem through habitat management. One way to manage habitat is to increase the role of wild plants around tea plants as refugia (Turista, 2011). Refugia is a term for wild plants that are used as natural enemies habitat. Habitat management is carried out to increase the number of natural enemy populations (Helenius in Rohman, 2008). Refugia plants are types of plants that can provide shelter, additional food sources, or microclimate which are beneficial for natural enemies, such as predators and parasitoids (Rohman, 2008). Plants favored by natural enemies are often wild plants and are categorized as weeds, which are wild plants that interfere with agriculture (Harahap and Tjahyono, 1994 in Kholishotin, 2002).

In the tea plantation area there are many types of animals that have ecological functions as pests, predators and parasitoids (Departement Pertanian, 2002). The types of predators, parasitoids and pests are incorporated in the Arthropod phylum. Arthropods really need to be preserved so that the balance of the ecosystem is maintained and the pests that attack tea plantations can be controlled naturally (without using pesticides). One way to protect Arthropods is to preserve their alternative hosts, which are wild plants.

Centella asiatica L. and Synedrella nodiflora L. Gaertn are wild plants existence can be found in the tea plantations. Based on Rohman's research (2008) on a laboratory scale using a wild plant olfactometer Centella asiatica L. and Synedrella nodiflora (L) Gaertn able to attract some Arthropods natural enemy.

Arthropods have different temporal distributions. Rhythm in insects is called a biological clock (Purwanti, 2011). Biological clocks allow Arthropods to determine when time to activity and to rest. The existence of a rhythm in insects results in the division of two living groups, namely diurnal (active during the day) and nocturnal (active at night). Arthropod temporal distribution can be used as a basis for when integrated pest management (IPM) is implemented. By knowing the temporal distribution of Arthropods, it is expected that the application of IPM will run well and on target.

The distribution of Arthropods in visiting wild plants shows that the Arthropods are interested in that wild plants and have used them as habitat. But how is the frequency of Arthropods daily visit in wild plants is still unknown. Based on the exposure that has been stated, it is necessary to conduct a research entitled "Frequency of Arthropods Daily Visits on Centella asiatica L. and Synedella nodiflora (L) Gaertn in the Wonosari Singosari Tea Plantation Area in Malang Regency".

\section{B. METHOD}

Research site conducted at the Tea Plantation Wonosari Singosari Malang Regency. The population in the study is all arthropods in the Tea Plantation Wonosari 
Singosari Malang Regency. The sample in the study are all arthropods observed in the same patch of Centella asiatica L. and Synedrlla nodiflora (L) Gaertn on tea clone TRI 2025 had been determined.

The tools used during this study include digital cameras, stationery, anemometer, Thermo hygrometer, lux meters, and binoculars for support this observation. As a supporter of determination required insect book "The Pest of Crops in Indonesia" (Kalshoven, 1981), "Destructive and Useful Insect Their Habits and Control" (Metcalf and Metcalf, 1992), and "Introduction to Lesson Insects (Borror, 1992).

In a preliminary observation is carried out surveys into the field, catch arthropods using insect nets, the identification of arthropods caught with books determination of insects, and observation exercises using visual methods of control. The purpose of preliminary observation is to memorize the type of arthropods in the tea plantation so that when the study only used visual methods without capturing to minimize the occurrence of ecosystem damage

Determination of plant observations using the method of cruising. The first step is to determine a swath of tea clones TRI 2025 and then explore the plot to see a sample of Centella asiatica L. and Synedrella nodiflora (L) Gaertn to be observed.

The observation method used "visual control" developed by Weisse and Sttetmer (1991) which has modificated. A visual method of control is a method of direct observation of arthropods visiting the footage of wild plants by the distance between the plant observations and observers as far as 2 meters and is done in a certain time.

Table 1. The temporal times of observed

\begin{tabular}{cll}
\hline Number & Centella asiatica $\mathbf{L}$. & Synedrella nodiflora $(\mathbf{L})$ Gaertn \\
\hline 1 & $7: 00-7: 15$ & $7: 20-7: 35$ \\
\hline 2 & $8: 00-8: 15$ & $8: 20-8: 35$ \\
\hline 3 & $9: 00-09: 15$ & $9: 20-9: 35$ \\
\hline 4 & $10: 00-10: 15$ & $10: 20-10: 35$ \\
\hline 5 & $11: 00-11: 15$ & $11: 20-11: 35$ \\
\hline 6 & $12: 00-12: 15$ & $12: 20-12: 35$ \\
\hline 7 & $13: 00-13: 15$ & $13: 20-13: 35$ \\
\hline 8 & $14: 00-14: 15$ & $14: 20-14: 35$ \\
\hline 9 & $15: 00-15: 15$ & $15: 20-15: 35$ \\
\hline 10 & $16: 00-16: 15$ & $16: 20-16: 35$ \\
\hline 11 & $17: 00-17: 15$ & $17: 20-17: 35$ \\
\hline
\end{tabular}

Arthropods were observed as many as 10 replicates consisting of 11 temporal with a duration of 15 minutes per day. The temporal times observed are presents in Table 1 above. The temporal time is repeated in 10 days. The data analysis was performed using descriptive statistical methods. Data related to the temporal distribution of frequency of Arthropods daily visits on Centella asiatica L. and Synedrela nodiflora (L) Gaertn presented in chart form and then interpreted descriptively.

\section{RESULTS AND DISCUSSION}

Daily visits Frequency of Arthropods on Centella asiatica L. and Synedrella nodiflora (L) Gaertn wild plant are fluctuating each time. This is due to the temporal distribution of arthropods have different. In the event of eating and being 
eaten arthropods can be divided into pests and natural enemies. Arthropod pests are herbivores while the natural enemies are carnivore arthropods. The frequency of Arthropod pests on Centella asiatica L. and Synedrella nodiflora (L) Gaertn wild plant is present to Figure 1, and the frequency of Arthropod natural enemies on Centella asiatica L. and Synedrella nodiflora (L) Gaertn wild plant is present to Figure 2.

Figure 1 shows that there are differences in the temporal distribution of pests in both wild plant Centella asiatica L. and Synedrella nodiflora (L) Gaertn. The highest visits of Gryllidae pests on wild plant Centella asiatica L. and Synedrella nodiflora (L) Gaertn there at 11.00. Gryllidae generally active at night (Kalshoven, 1981), but the observation was found that both in Centella asiatica L. and Synedrella nodiflora (L) Gaertn Gryllidae have the highest traffic at 11:00. This may be due to environmental conditions in the tea gardens are always foggy, so the light intensity and temperature to be low and Gryllidae thought it was still night. Darmawan (2008) explains that the presence of animals in a place determined by the conditions and environmental factors in place, allowing the species to continue his life (eating and breeding).
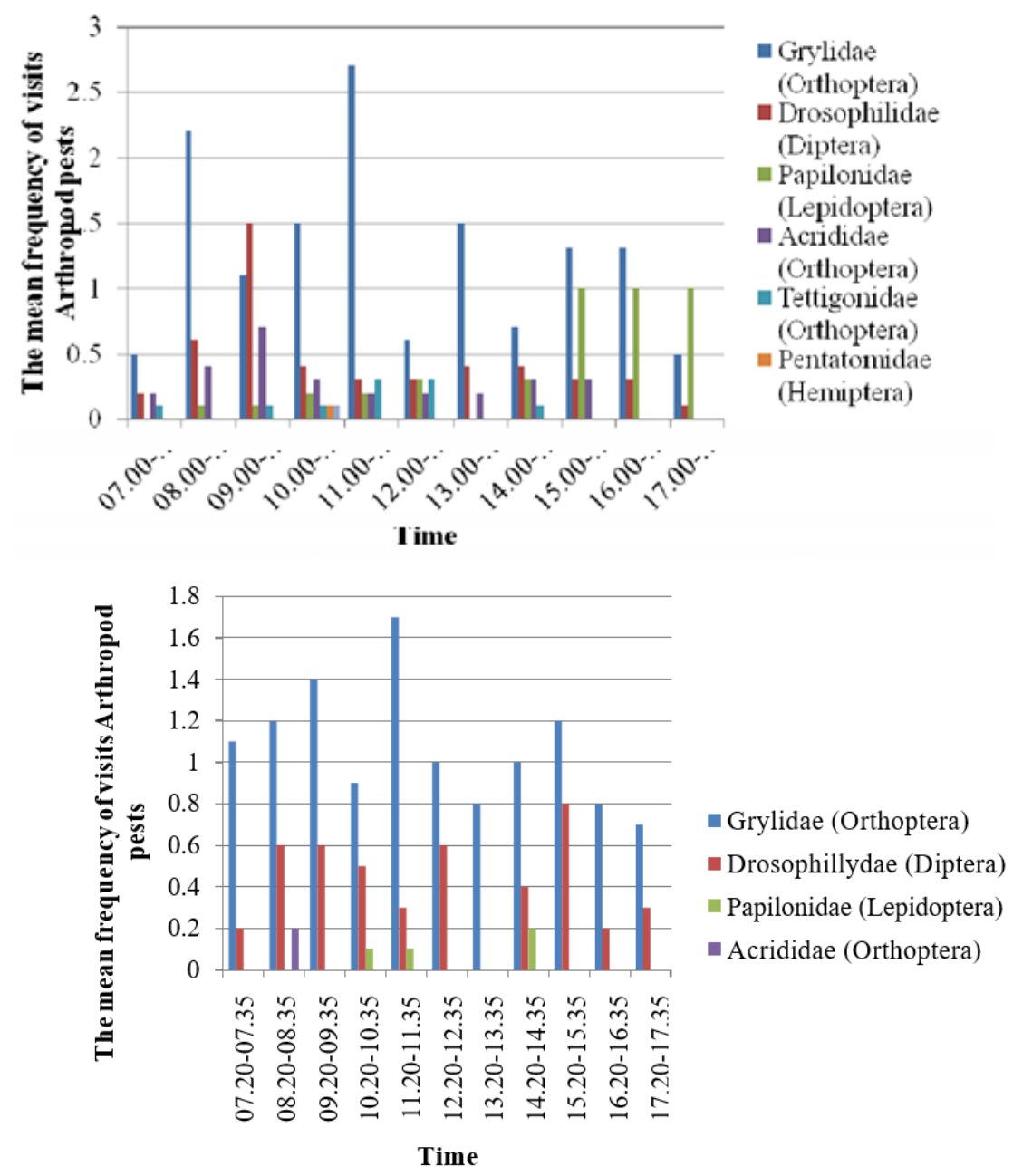

Figure 1 The mean frequency of visits Arthropod pests: a) on the wild plant Centella asiatica L. b) on the wild plants Synedrella nodiflora (L) Gaertn

The highest visits of Drosophyllidae in Centella asiatica L. occurs at 09.00 and on wild plants Synedrella nodiflora (L) Gaertn occurs at 15:20. This is related to abiotic factors that support its activities. At 09.00, the lux light intensity is 678.5, the temperature 
is $24.3 \mathrm{o}$ C, the humidity is $75.6 \%$, and the wind speed is $1388 \mathrm{~m} / \mathrm{s}$. At $15: 20$, the lux light intensity is 678.5 , the temperature is $24.3 \mathrm{o} \mathrm{C}$, the humidity is $75.6 \%$, and the wind speed is $1218 \mathrm{~m} / \mathrm{s}$. At 9:00 and 15:20 abiotic factors are relatively equal. Odum (1993) states that the insect has a specific temperature range where he can live. Outside the temperature range of insects will die of cold or heat. Humidity controls the sharing of activity among other animals, motor activity, and food (Susanto, 2000). Many types of insects have a narrow tolerance limit against moisture.

In the Centella asiatica L. wild plant, Acrididae visits occurred during the observation time, but the visit was highest at 09.00. In the Synedrella nodiflora (L) Gaertn wild plnt, Acrididae only visit at 8:20. This is in accordance with the opinion Suheriyanto (2008) which states that herbivorous arthropods spent much of his life by being around plants, take the plant, and took the plant and use it for survival and reproduction. In addition, Kalshoven (1981) also stated that the Acrididae generally active throughout the day. During the observation, Acrididae is only one visit to Synedrella nodiflora (L) Gaertn. This is probably due to the Acrididae not native wild plant pests Synedrella nodiflora (L) Gaertn but only perform the migration. Individuals of a population can be scattered out of the population to other places (Oka, 2005).

During the observation, Papilionidae has visited in the morning, afternoon, and evening. This is related to active time, namely during the day. The butterfly is a diurnal insect that plays a role in the balance of the ecosystem, helps pollination of plants and bioindicator changes in environmental quality (Purwaningsih et al., 2015) Visits Papilionidae highest in wild plants Centella asiatica L. occurred at 15:00 to 17:20, whereas in wild plants Synedrella nodiflora (L) Gaertn highest visits occur at 14:20.

Based on the observation, each arthropod pests have the highest frequency of visits at different times. This is influenced by abiotic factors that can tolerance and long time host of the invention. Nugroho (2008) stated that some insects take a long time in the space around the sample to find the source of the smell that drew him and some did not take a long time. Tettigoniidae, Pentatomidae, and frequency of visits Cucurlionidae have a few and not always found in every observation time. This may be due to the family Tettigoniidae, Pentatomidae, and Cucurlionidae migrant pests. 


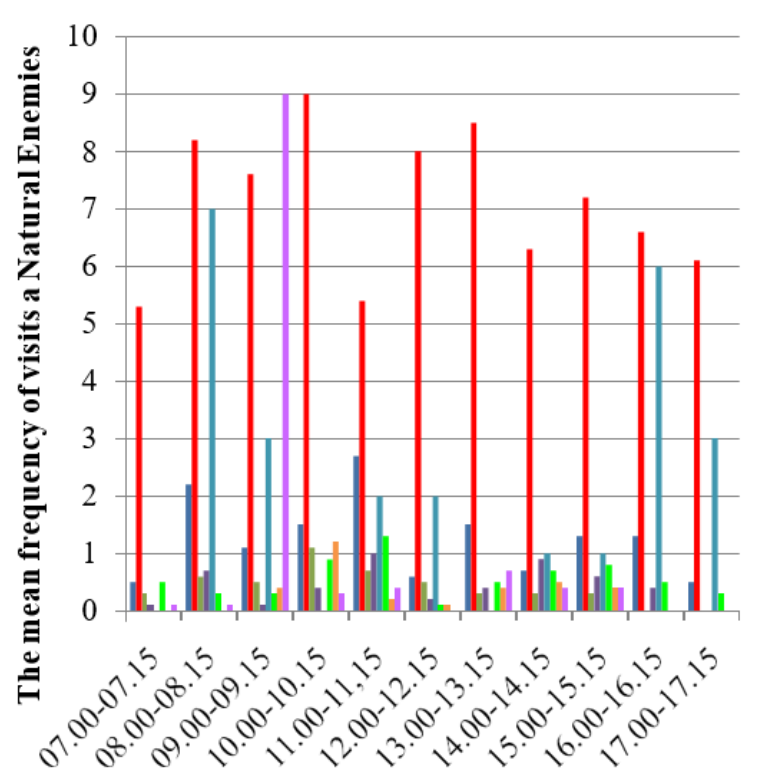

Time

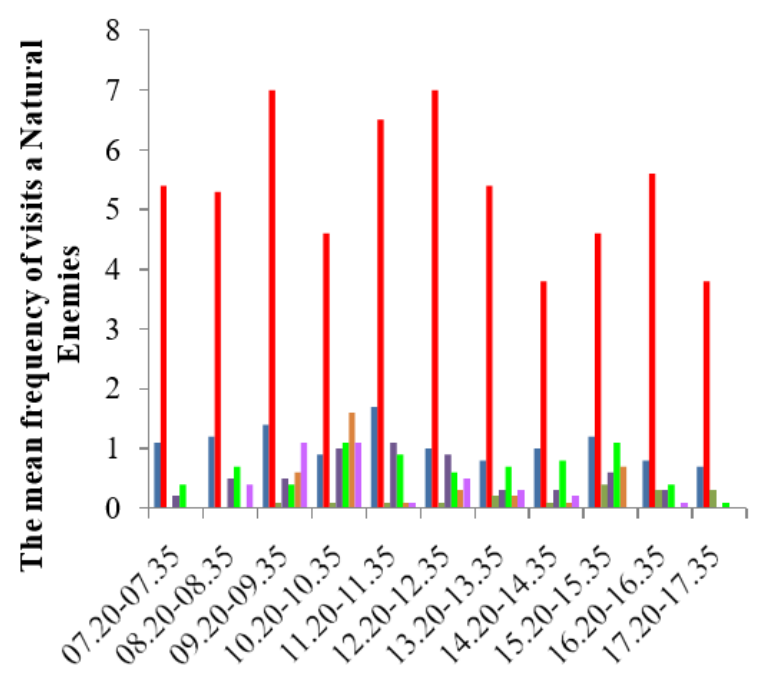

Time

\section{- Gryllidae (Orthoptera)}

- Formicidae (Hymenoptera)

- Coccinellidae (Coleoptera)

- Syrpidae (Diptera)

- Culicidae (Diptera)

- Lycosidae (Araneae)

- Vespidae (Hymenoptera)

- Dollichopopidae (Diptera)

- Grylidae (Orthoptera)

- Formicidae (Hymenoptera)

- Coccinellidae (Coleoptera)

- Syrpidae (Diptera)

Lycosidae (Araneae)

- Vespidae (Hymenoptera)

Dollichopopidae (Diptera)

Figure 2 The mean frequency of visits a Natural Enemies: a) on Wild Plant Centella asiatica L. b) on Wild Plant Synedrella nodiflora (L) Gaertn

Figure 2 shows that there are differences in the temporal distribution of natural enemies in both Centella asiatica L. and Synedrella nodiflora (L) Gaertn wild plant. Natural enemies that have discussed only the high frequency of visits. In the Centella asiatica L. wild plant, they are Gryllidae, Formicidae, Coccinellidae, Syrpidae, Culicidae, Lycosidae, Vespidae, Dollichopopidae. In the Synedrella nodiflora (L) Gaertn wild plant, they are Formicidae, Gryllidae, Syrpidae, Dollichopopidae, Vespidae, Lycosidae, and Coccinellidae.

Formicidae dominates Centella asiatica L. and Synedrella nodiflora (L) Gaertn wild plants. This family has the highest number of visits and can always be found at each time of observation. The highest visits of Formicidae because they are alive and doing activities together. Rahmawaty (2000) stated that the Formicidae can reach $70 \%$ of the population of tropical soil fauna, so the family can be easily found in large numbers. 
Formicidae also has a high tolerance limit of the food so that survival is not constrained by shortages of food and the population becomes very large. In the Centella asiatica L. wild plant, Formicidae highest visits occurred at 10:00 while on Synedrella nodiflora (L) Gaertn wild plants, the highest visits of Formicidae occurs at 09:20 and 12:20. Formicidae visit each rise and fall time is affected by migration. Formicidae is a social creature, so in general, Formicidae migrating in large numbers. This is supported by Metcalf and Metcalf (1981) which states that all Formicidae are social insects and live in colonies composed of castes.

Coccinellidae are found throughout the observation time. Coccinellidae on Centella asiatica L. wild plant has the highest visits at 11:00. In the wild Synedrella nodiflora (L) Gaertn, the highest visits of Coccinellidae at 15:20. This is in accordance with the Tobing (2007) and Wagiman (1997) which states that the activities of these predatory beetles eat higher in periods of light than dark periods.

Syrpidae has the highest visits on wild plant Centella asiatica L at 14.00 while in the wild Synedrella nodiflora (L) Gaertn highest visit of Syrpidae at 15:20. During the observations, Culicidae have visits in the morning, afternoon, and evening. This is because the Culicidae are diurnal animals (Guimaraes, 2000).

Lycosidae found almost all the time either on wild plants Centella asiatica L. and Synedrella nodiflora (L) Gaertn. This is in accordance with the Barry (2010) which states that the Lycosidae are jumping spiders active throughout the day, makes no nest, but roam the plant looking for prey and may pounce on its prey quickly, it can even catch a fly in flight and can capture prey bigger than his body. During observations, also found that Lycosidae has a high frequency of visits. The number of visits Lycosidae influenced by vegetation structure in the vicinity. Foelix (1996) suggests that the spider's community is highly dependent on the plant community. The highest visits of Lycosidae in Centella asiatica L. wild plants occurred at 10:00 while on Synedrella nodiflora (L) Gaertn wild plants at 11:20.

Vespidae visiting Centella asiatica L. and Synedrella nodiflora (L) Gaertn wild plants start at 09.00 until 15:20. This is because the Vespidae are diurnal insects (Koerniawan, 2005). The highest visits of Vespidae in Centella asiatica L. wild plants occurs at 14.00 while in the wild Synedrella nodiflora (L) Gaertn at 15:20. The highest visits of Dollichopopidae in Centella asiatica L. wild plants occurs in 09.00 while in the Synedrella nodiflora (L) Gaertn wild plants at 08:20.

Every family of arthropod has the different highest visits at different plants. This is influenced by abiotic and biotic factors. Suheriyanto (2008) states that insect populations can not increase to infinity but showed uncontrolled fluctuations caused by the interaction between the insect population with the environment, including weather, food, shelter, and natural enemies. Also, visit a different highest in plants of different habits are also caused by natural enemies that often forage in different places for different meal times. Borror (1992) stated that they (predators) live apart from their victims and often look for insects in different places for different meal times. Natural enemies other than mentioned have a very low frequency of visits. This is possible because natural enemies are migratory animals. 


\section{CONCLUSION}

Based on the results obtained the conclusion of Centella asiatica L. wild plant visited by 14 family where 7 families are pests (Gryllidae, Drosophilidae, Papilionidae, Acrididae, Tettigonidae, Pentatomidae, and Cucurlionidae) and 8 families are natural enemies (Gryllidae, Formicidae, Coccinellidae, Syrpidae, Culicidae, Lycosidae, Vespidae, and Dollichopopidae) while Synedrella nodiflora (L) Gaertn wild plant visited by 10 families where 4 families are pests (Gryllidae, Drosophillidae, Papilionidae, and Acrididae) and 7 families are natural enemies (Gryllidae, Formicidae, Coccinellidae, Syrpidae, Lycosidae, Vespidae, and Dollichopopidae). Every family of Arthropod has the different highest visits at different plants. This is influenced by abiotic and biotic factors.

\section{E. REFERENCES}

. 2011. Kupu-kupu. (Online). (http://id.wikipedia.org/wiki/Kupu-kupu, diakses tanggal 29 Mei 2011).

Barry, Muhammad Nuim. 2010. Peran Ekologis dan Distribusi Temporal Arthropoda Pengunjung Ageratum conyzoides (L) dan Blummea sp. (L) di Lahan Budidaya Porang Madiun. Skripsi. Tidak diterbitkan. Malang: jurusan Biologi FMIPA Universitas Brawijaya Malang.

Borror, T dan Johson. 1992. Pengenalan Pelajaran Serangga. Yogyakarta: Gadjah Mada University Press.

Darmawan, Eko. 2008. Perbanyakan Tanaman Teh.(Online)

http://pengawasbenihtanaman.blogspot.com/2008_06_01_archive.html. Diakses pada tanggal 21 Januari 2011.

Departement Pertanian. 2002. Musuh Alami Hama dan Penyakit Tanaman Teh. Proyek Pengendalian Hama Terpadu Perkebunan Rakyat Direktorat Perlindungan Perkebunan, Direktorat Jenderal Bina Produksi Perkebunan. Jakarta.

Foelix, R. F. 1996. Biology of Spider. Second Edition. New york. Oxford Univ Pr and Georg Verlag. P. 110-149.

Guimaraes, A.E., C.Gentile, C.M. Lopes, R.P. de Mello. 2000. Ecology of Mosquitoes (Diptera: Culicidae) in Areas of Serra do Mar State Park, State of São Paulo, Brazil. III - Daily Biting Rhythms and Lunar Cycle Influence. Mem Inst Oswaldo Cruz, Rio de Janeiro, Vol. 95(6): 753-760, Nov./Dec. 2000.

Kalshoven, L. G. E. 1981. Pest of Crops in Indonesia, Revised by P. A Vander Lann University of Amsterdam. Jakarta: P.T Ichtiar Baru-van Hoeve.

Koerniawan, Novi Indrawanto. 2005. Distribusi Temporal Arthropoda Diurnal Pengunjung Tanaman Kersen (Muntingia calabura L) dan tanaman Belimbin (Averrhoa carambola L). Malang: Program Studi Biologi Universitas Brawijaya.

Kholishotin. 2002. Preferensi Serangga Predator Adalia Sp Terhadap Tanaman Familia Asteraceae dan Kombinasinya. Skripsi tidak diterbitkan. Malang: Universitas Islam Malang.

Kwenti, T. E. 2017. Biological Control Parasite. London: Intech Open.

Metcalf, R.L., \& Metcalf, E.L. 1992. Destructive and Useful Insect Their Habits and Control. New York: Chapmann and Hall. 
Nugroho, Fitra Agung. 2008. Preferensi Serangga Family Coccinellidae Terhadap Bau Beberapa Jenis Tumbuhan di Sekitar Kebun Porang Madiun. Skripsi: Universitas Brawijaya Malang.

Odum. 1993. Dasar-Dasar Ekologi: Edisi ketiga. Terjemahan oleh Tjahjono Samingan.Yogyakarta: Gadjah Mada University Press.

Oka, Ida Nyoman. 2005. Pengendalian Hama Terpadudan Implementasinya di Indonesia.

Yogyakarta: Gadjah Mada University Press.

Purwaningsih, A. D., Manjaswari, A., Pamungkas, D. W. 2015. Keanekaragaman KupuKupu (Sub Ordo: Rhopalocera) Di RPH Sarangan BKPH Lawu Selatan. BioWallacea Jurnal Ilmiah Ilmu Biologi. 1 (3): 174-176.

Purwanti, Dewi. 2011. Perilaku Serangga. Jatinangor: Jurusan Biologi Universitas Padjadjaran.

Rahmawati. 2000. Study Keanekaragaman Mesofauna Tanah di Kawasan Hutan Wisata Alam Sibolangit (Desa Sibolangit, Kecamatan Sibolangit, Kabupaten Daerah Tingkat II Deli Serdang Propinsi Sumatera Utara). Jurusan Kehutanan Universitas Sumatera Utara.

Rohman, Fatchur. 2008. Struktur Komunitas Tumbuhan Liar dan Arthropoda Sebagai Komponen Evaluasi Agroekosistem di kebun Teh Wonosari Singosari Kabupaten Malang. Disertasi. Tidak diterbitkan. Malang: Universitas Brawijaya.

Styamidjaja, D. 2000. Teh Budidaya dan Pengolahan Pascapanen. Yogyakarta: Kanisius. Suheriyanto, Dwi. 2008. Ekologi Serangga. Malang: UIN Malang Press.

Susanto, P. 2000. Pengantar Ekologi Hewan. Jakarta: Proyek Pengembangan Guru Sekolah Menengah. IBRD Loan No 3979 Dirjen Pendidikan Dekan Tingkat Departemen Nasional.

Tobing, M. C. Dan Nasution, D. B. Biologi Predator Cheilomenes sexmaculata (Fabr.) (Coleoptera: Coccinellidae pada Kutu Daun Macrosiphoniela sanborni Gilette (Homoptera: Apidae).

Turista, D.D.R. 2011. Studi Kunjungan Harian Arthropoda Pada Tumbuhan Liar Centella asiatica L. dan Synedrella nodiflora L. Gaertn di Area Kebun The Wonosari Singosari Kabupaten Malang. Skripsi. Tidak Diterbitkan. Malang: Universitas Negeri Malang.

Wagiman , F.F. 1997. Ritme Aktivitas Harian Menochilus sexmaculata Memangsa Aphis cracivora. Prosiding Kongres Perhimpunan Entomologi indonesia V dan Simposium Entomologi. Bandung. Pp. 278-280.

Weisse, E and Stetmer, C. 1991. Unkraufterin Der Agrariandschaft Locken Blutenbesuchende Nutzinsekten An. Stuttgart: Haupt Germany. 